\title{
Seasonal variation in the content of tannins in barks of barbatimão species
}

\author{
Suzana C. Santos ${ }^{1 *}$, Wesley F. Costa ${ }^{1}$, Fernando Batista ${ }^{1}$, Lúcio R. Santos ${ }^{1}$, Pedro H. Ferri ${ }^{1}$, \\ Heleno D. Ferreira', José C. Seraphin ${ }^{3}$ \\ ${ }^{1}$ Laboratório de Bioatividade Molecular, IQ, Universidade Federal de Goiás, CP 131, 74001-970, Goiânia, GO, \\ Brazil, \\ ${ }^{2}$ Departamento de Biologia Geral, ICB, Universidade Federal de Goiás, CP 131, 74001-970, Goiânia, GO, Brazil, \\ ${ }^{3}$ Núcleo de Estatística Aplicada-IME, Universidade Federal de Goiás, CP 131, 74001-970, Goiânia, GO, Brazil
}

\begin{abstract}
RESUMO: "Variação sazonal dos teores de taninos em cascas de espécies de barbatimão". A composição de taninos em cascas de espécies de barbatimão, Stryphnodendron adstringens (Mart.) Cov. and S. polyphyllum (Mart.), foi analisada mensalmente durante um ano. Os resultados foram correlacionados com as condições climáticas do período de coleta (precipitação, umidade e temperatura média) através de métodos quimiométricos. Análise de componentes principais dos dados mostrou uma tendência de maior produção de taninos na estação quente e chuvosa, sugerindo que os fatores ambientais podem afetar os teores de taninos nestas espécies.
\end{abstract}

Unitermos: Stryphnodendron adstringens, Stryphnodendron polyphyllum, Barbatimão, taninos condensados.

\begin{abstract}
The contents of tannins in the barks of barbatimão species, Stryphnodendron adstringens (Mart.) Cov. and S. polyphyllum (Mart.), were analysed monthly during one year. Results were correlated with climate conditions (rainfall, humidity and mean temperature) by chemometric methods. Principal component analysis of the data showed a tendency for higher production of tannins in the warm and wet season, suggesting that environmental factors can affect the levels of tannins in those plants.
\end{abstract}

Keywords: Stryphnodendron adstringens, Stryphnodendron polyphyllum, Barbatimão, condensed tannins.

\section{INTRODUCTION}

Stryphnodendron adstringens (Mart.) Coville and S. polyphyllum Mart., Leguminosae-Mimosoideae, both known as barbatimão are extensively used in folk medicine for the treatment of diarrhoeas, gynaecological problems and as wound healing (Nunes et al., 2003; Macedo; Ferreira, 2004). Previous studies showed significant cicatrizant properties (Panizza et al., 1988; Neto et al., 1996), anti-inflammatory activity (Lima; Martins; Souza, 1998; Falcão et al., 2005), antiparasitic activity against Trypanosoma cruzi (Herzog-Soares et al., 2002) and gastric antiulcerogenic effects (Audi et al., 1999) for the stem bark crude extract from $S$. adstringens. The importance of this plant promoted its inclusion in Brazilian Pharmacopoeia (Brandão et al., 2006). Pharmacological activities of these plants are mainly due to the tannins present in their barks. Although both species are rich in condensed tannins, a comparison of their tannin level showed $S$. polyphyllum being more astringent (Santos et al., 2002; Ardisson et al., 2002).
Many factors, such as soil composition, water stress, temperature and humidity, can affect the levels of phenolics present in plants (Kouki; Manetas, 2002; Monteiro et al., 2006). Tannin amounts alter during the development of the plant and also as a response to the environmental changes (Hatano et al., 1986; Salminen et al., 2001). These variations influence directly the quality of the plant for medicinal use. In the present study we investigate the correlation between climate factors, such as temperature, precipitation (rainfall) and humidity, and seasonal variations on the levels of tannins from the bark of both barbatimão species. The results obtained will presumably contribute to an understanding of the metabolism of tannins in these plants and also they will be useful for knowledge of the best period for bark collection.

\section{MATERIAL AND METHODS}

Plant material and climatic data 
Barks of each species were collected monthly during the period between June/97 and May/98 at the outskirts of the city of Goiânia and identified by Prof. Heleno D. Ferreira. Vouchers were deposited in the Herbarium of the Universidade Federal de Goiás (code number 25535 and 25700). Climate conditions of the period of the study were furnished by the Estação Evaporimétrica de $1^{\circ}$ classe- Setor de Engenharia Rural, Escola de Agronomia, UFG).

\section{Extraction}

Dried and ground barks $(10 \mathrm{~g})$ of each species were extracted by stirring in an erlenmeyer at room temperature with acetone:water 7:3 (4 x $100 \mathrm{~mL})$. Each extract was evaporated under vacuum to $30 \%$ volume and filtered to remove fats and then freeze-dried.

\section{Colorimetric assays}

Total phenolics assay: $\mathrm{FeCl}_{3}$ (Synth) was added to each extract solution $(0.5 \mathrm{mg} / \mathrm{mL})$ under alkaline conditions to produce a coloured complex with phenols, which was read at $510 \mathrm{~nm}$, following the Hagerman and Butler method (1978), adapted by Mole and Waterman (1987). All solutions were analysed in triplicate. The standard curve was constructed with tannic acid (Merck) at the following dilutions: $0.08,0.2,0.4,0.6,0.8,1.0 \mathrm{mg} /$ $\mathrm{mL}$. The correlation coefficient calculated for this curve was $r=0.99983$.

Condensed tannins assay: The proanthocyanidin method (Mole; Waterman, 1987) was used. It involves an acid depolymerisation of the extracts solutions $(0.5$ $\mathrm{mg} / \mathrm{mL}$ ) in butanol, yielding anthocyanidin products. Absorbance was read at $550 \mathrm{~nm}$. All solutions were analysed in triplicate. The standard curve was constructed with Quebracho tannin (Hagerman, A.E., Miami University) at the following dilutions: $0.2,0.4,0.6,0.7$, $0.9,1.2,1.4 \mathrm{mg} / \mathrm{mL}$. The correlation coefficient calculated for this curve was $r=0.99981$.

Protein precipitation assay: Hagerman and Butler method (1978) uses Bovine Serum Albumine (BSA; fraction V, Sigma) solution $(1.0 \mathrm{mg} / \mathrm{mL})$ in 0.2 $\mathrm{M}$ acetate buffer ( $\mathrm{pH}$ 4.9). The extract solutions were precipitated with BSA and after centrifugation, the precipitate was dissolved in sodium dodecyl sulfate (Sigma)/triethanolamine (Merck) solution and the tannins were complexed with $\mathrm{FeCl}_{3}$. The coloured complex was read at $510 \mathrm{~nm}$. Measurements were made in the range $0.2<\mathrm{A}<0.9$. All solutions were analysed in triplicate. The standard curve was constructed with tannic acid at the following dilutions: $0.2,0.4,0.5,0.6,0.8,1.0,1.5 \mathrm{mg} / \mathrm{mL}$. The linearity range was between 0.2 to $0.6 \mathrm{mg} / \mathrm{mL}$. The correlation coefficient for this range was $r=0.99932$.

\section{Statistical analyses}

Principal component analysis (PCA) and Cluster analysis (CA), using SPAD.N software package (Lebart et al., 1994), was applied to examine the interrelationships between the climatic data and their polyphenol content. From PCA, correlation matrix, eigenvalue and eigenvector evaluation showed that the whole data set could be projected in the space defined by the first three principal components retaining significant percentage of the total variance in this projection. Nearest neighbour complete linkage technique by Benzécri algorithm (Benzécri, 1980) was used as an index of similarity and hierarchical clustering was performed according to the Ward's variance minimising method (Ward, 1963).

\section{RESULTS AND DISCUSSION}

Stryphnodendron adstringens and $S$. polyphyllum are semi-deciduous trees well adapted to dry regions. They are native of Brazilian Cerrado, a region characterised by two seasons: dry (April to September) and wet (October to March). Fructification of both species occurs during the dry season (July to September), when part of the leaves falls, and flowering happens in the beginning of the rains, in the late spring.

Barks collected monthly were assayed to total phenolics, condensed tannins and tannins (protein precipitation assay). Results listed in Table 1 were correlated with climate conditions (rainfall, humidity and mean temperature, Table 2) by chemometric methods.

A combination of CA and PCA showed the existence of two principal clusters. The majority of the data could be represented in three main axes, which contained $90.8 \%$ of total variance $(\mathrm{x}=41.8, \mathrm{y}=30.0$ and $\mathrm{z}=19.0 \%$; Fig. 1).

Cluster I (Fig. 1 and 2) was characterised by lower levels of total phenols, condensed tannins and protein precipitation and also lower average of mean temperature $\left(23.9 \pm 2.0^{\circ} \mathrm{C}\right)$, humidity $(58.6 \pm 9.7 \%)$ and precipitation $(64.7 \pm 97.8 \mathrm{~mm})$, which occurred in June, August, September, November and May.

Cluster II (Fig. 1 and 2) presented the opposite behaviour: high levels of total phenols, condensed tannins and protein precipitation, which occurred in October, December, January, February and March, where the average of mean temperature $\left(25.5 \pm 0.8^{\circ} \mathrm{C}\right)$, humidity $(69.8 \pm 6.4 \%)$ and precipitation $(209.5 \pm 89.5 \mathrm{~mm})$ were also high. Maximum of tannins, for both species, were observed in the flowering period, October for $S$. adstringens and December for $S$. polyphyllum.

In both clusters (Fig. 2), the average in the levels of total phenols, condensed tannins and tannins (protein precipitation) were higher for $S$. polyphyllum, which is in accordance with previous study (Santos et al., 2002). Only in October the levels of total phenols, condensed tannins and tannins were higher for S. adstringens, which can be correlated with the peak of flowering for this plant in this month. 
Table 1. Concentration of total phenolics and tannins in $\mathrm{mg} / \mathrm{g}$ dry weight ( \pm standard deviation) of barbatimão species.

\begin{tabular}{lcccccccc}
\hline Species & \multicolumn{4}{c}{ S. adstringens } & \multicolumn{4}{c}{ S. polyphyllum } \\
\hline Months & E.Y. & \multicolumn{1}{c}{ T.P. } & \multicolumn{1}{c}{ C.T. } & \multicolumn{1}{c}{ P.P } & E.Y. & T.P. & C.T. & P.P \\
\hline JUN/97 & 21.2 & $81.0 \pm 0.1$ & $490.0 \pm 1.5$ & $69.0 \pm 0.1$ & 24.2 & $119.6 \pm 0.1$ & $703.9 \pm 1.0$ & $107.1 \pm 0.1$ \\
AUG/97 & 19.9 & $78.0 \pm 0.1$ & $449.8 \pm 0.5$ & $61.9 \pm 0.2$ & 30.1 & $153.6 \pm 0.2$ & $899.5 \pm 1.6$ & $126.8 \pm 0.1$ \\
SEP/97 & 23.1 & $114.3 \pm 0.1$ & $713.0 \pm 0.3$ & $115.2 \pm 0.1$ & 22.4 & $93.3 \pm 0.2$ & $563.2 \pm 0.5$ & $81.0 \pm 0.05$ \\
OCT/97 & 31.5 & $181.5 \pm 0.2$ & $1156.3 \pm 2.2$ & $181.5 \pm 0.1$ & 29.1 & $157.6 \pm 0.2$ & $958.2 \pm 2.6$ & $130.4 \pm 0.1$ \\
NOV/97 & 13.0 & $62.3 \pm 0.1$ & $377.8 \pm 0.3$ & $58.5 \pm 0.1$ & 13.5 & $70.6 \pm 0.1$ & $492.8 \pm 0.5$ & $63.2 \pm 0.1$ \\
DEC/97 & 17.7 & $76.5 \pm 0.1$ & $472.7 \pm 1.4$ & $67.5 \pm 0.2$ & 31.6 & $176.6 \pm 0.2$ & $1131.7 \pm 1.7$ & $145.7 \pm 0.1$ \\
JAN/98 & 19.6 & $101.4 \pm 0.1$ & $617.1 \pm 0.8$ & $106.5 \pm 0.2$ & 28.6 & $150.0 \pm 0.2$ & $830.5 \pm 2.3$ & $124.1 \pm 0.2$ \\
FEB/98 & 7.9 & $36.0 \pm 0.2$ & $211.6 \pm 0.7$ & $39.0 \pm 0.05$ & 32.6 & $195.3 \pm 0.2$ & $892.0 \pm 2.5$ & $141.4 \pm 0.2$ \\
MAR/98 & 21.9 & $142.5 \pm 0.1$ & $621.1 \pm 0.7$ & $144.0 \pm 0.2$ & 25.9 & $142.0 \pm 0.1$ & $727.1 \pm 0.9$ & $113.6 \pm 0.2$ \\
MAY/98 & 6.5 & $32.3 \pm 0.05$ & $160.2 \pm 0.1$ & $28.5 \pm 0.06$ & 17.6 & $87.0 \pm 0.1$ & $47.01 \pm 0.5$ & $70.4 \pm 0.04$ \\
\hline
\end{tabular}

E.Y.= Extraction yield (\%), T.P.= Total phenols, C.T.= Condensed tannins, P.P.= Protein precipitation

Table 2. Climate conditions in the period of the study

\begin{tabular}{lccc}
\hline Months & Mean Temperature $\left({ }^{\circ} \mathrm{C}\right)$ & Humidity $(\%)$ & Precipitation $(\mathrm{mm})$ \\
\hline JUN/97 & 20.56 & 64.99 & 10.22 \\
AUG/97 & 23.78 & 42.22 & 0.0 \\
SEP/97 & 26.07 & 53.11 & 33.33 \\
OCT/97 & 26.67 & 57.78 & 72.22 \\
NOV/97 & 25.71 & 68.89 & 266.67 \\
DEC/97 & 24.29 & 71.78 & 144.44 \\
JAN/98 & 25.33 & 73.89 & 244.44 \\
FEB/98 & 25.56 & 75.89 & 322.22 \\
MAR/98 & 25.89 & 69.67 & 264.44 \\
MAY/98 & 23.33 & 63.89 & 13.33 \\
\hline
\end{tabular}

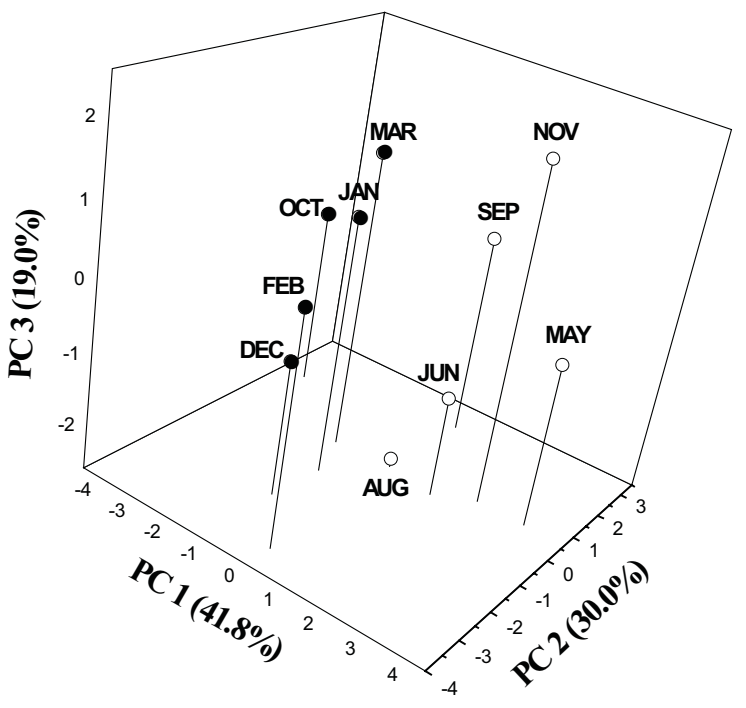

Figure 1. Scatter plot of tannins seasonal variation of $S$. adstringens and $S$. polyphyllum on the three main axes of the PCA. Two general areas are clearly separated, each for a specific distribution of total phenols, condensed and precipitable tannins belonging to the same climatic data: cluster I $(\mathrm{O})$ and cluster II $(\bullet)$. 

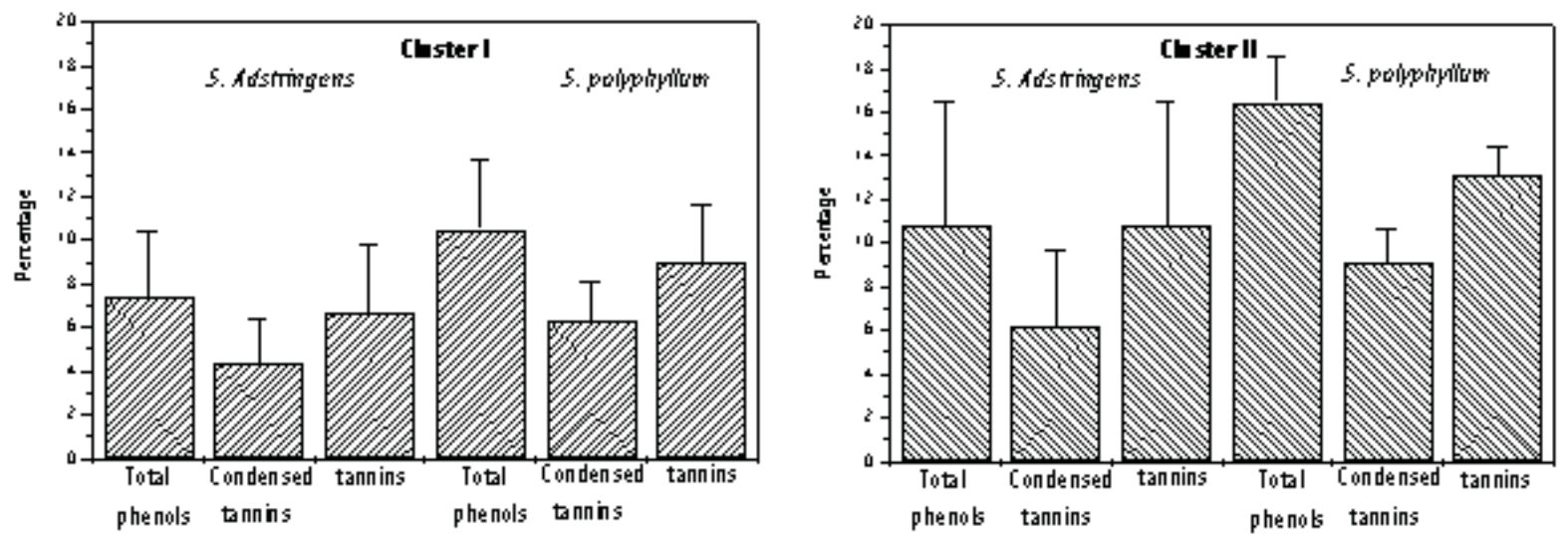

Figure 2. Mean chemical composition of total phenols, condensed and precipitable tannins of clusters from $S$. adstringens and S. polyphyllum. Vertical lines show \pm standard deviations.

Seasonal variations in leaf tannins have already been reported for deciduous trees such as: Quercus robur (Feeny, 1970) and Betula pubescens (Salminen et al., 2001). These variations occurred during leaf growth and development, from spring to fall, and were related with herbivore resistance of plants. In the present study only bark tannins were evaluated and they also showed seasonal variations.

The statistical analyse (PCA and CA) suggested that environmental factors could affect strongly the production of tannins by both species of barbatimão, being probably the main factor the shortage or the excess of water. During the dry season, plants in Cerrado region are under drought stress and carbon-based secondary metabolites are reduced (Horner, 1990). On the other hand, in the wet season there is an increase in the primary metabolism of barbatimão, as new leaves and flowers are produced. The wet and warm weather also enhances the proliferation of insects and pathogenic microrganisms, which means a need for a higher level of endogenous defences, such as condensed tannins and other phenols.

Barks collected in the wet season should be preferable for medicinal uses, as the contents of active compounds are higher in this period.

\section{ACKNOWLEDGMENTS}

The authors are indebted to CNPq/PCOP (Grant No. 520769/99-6), PADCT III (Grant No. 620166/97-5) and Fundação de Apoio à Pesquisa - FUNAPE/UFG.

\section{REFERENCES}

Ardisson L, Godoy JS, Ferreira LAM, Stehmann JR, Brandão MGL 2002. Preparação e caracterização de extratos glicólicos enriquecidos em taninos a partir das cascas de Stryphnodendron adstringens (Mart.) Coville (Barbatimão). Rev Bras Farmacogn 12: 27-34.
Audi EA, Toledo DP, Peres PG, Kimura E, Pereira WKV, Mello JCP, Nakamura C, Prado WA, Cuman RKN, Amado CAB 1999. Gastric antiulcerogenic effects of Stryphnodendron adstringens in rats. Phytother Res 13: 264-266.

Benzécri JP 1980. L'Analyse Des Données: La Taxinomie, Tome 1, Paris: Dunod.

Brandão MGL, Cosenza GP, Moreira RA, Monte-Mor RLM 2006. Medicinal plants and other botanical products from the Brazilian Official Pharmacopoeia. Rev Bras Farmacogn 16: 408-420.

Falcão HS, Lima IO, Santos VL, Dantas HF, Diniz MFFM, Barbosa-Filho JM, Batista LM 2005. Review of the plants with anti-inflammatory activity studied in Brazil. Rev Bras Farmacogn 15: 381-391.

Feeny P 1970. Seasonal changues in oak leaf tannins and nutrients as a cause of spring feeding by winter moth caterpillar. Ecology 51: 565-581.

Hagerman AE, Butler LG 1978. Protein precipitation method for the quantitative determination of tannins. J Agric Food Chem 26: 809-812.

Hatano T, Kira R, Yoshizaki M, Okuda T 1986. Seasonal changes in the tannins of Liquidanbar formosana reflecting their biogenesis. Phytochemistry 25: 2787-2789.

Herzog-Soares JD, Alves RK, Isac E, Bezerra JCB, Gomes MH, Santos SC, Ferri PH 2002. Atividade tripanocida in vivo de Stryphnodendron adstringens (barbatimão verdadeiro) e Caryocar brasiliensis (pequi). Rev Bras Farmacogn 12(Supl. 1): 1-2.

Horner JD 1990. Nonlinear effects of water deficits on foliar tannin concentration Biochem Syst Ecol 18: 211-213.

Kouki M, Manetas Y 2002. Resource availability affects differentially the levels of gallotannins and condensed tannins in Ceratonia siliqua. Biochem Syst Ecol 30: 631-639.

Lebart L, Morineau A, Lambert T, Pleuvret P 1994. Spad. $\mathrm{N}$ Version 2.5. Sistema compatible para el análisis de datos. Centre International de Statistique et d'Informatique Appliqueés, Saint Mandé, France.

Lima JCS, Martins DTO, Souza PT Jr 1998. Experimental evaluation of stem bark of Stryphnodendron adstringens (Mart.) Coville for anti-inflammatory 
activity. Phytother Res 12: 218-220.

Macedo M, Ferreira AR 2004. Plantas medicinais usadas para tratamentos dermatológicos, em comunidades da Bacia do Alto Paraguai, Mato Grosso. Rev Bras Farmacogn 14(Supl. 1): 40-44

Mole S, Waterman PG 1987. A critical analysis of techiniques for measuring tannins in ecological studies. Oecologia 72: $137-147$.

Monteiro JM, Albuquerque UP, Lins Neto EMF, Araújo EL, Albuquerque MM, Amorim ELC 2006. The effects of seasonal climate changes in the Caatinga on tannin levels in Myracrodruon urundeuva (Engl.) Fr. All. and Anadenanthera colubrina (Vell.) Brenan. Rev Bras Farmacogn 16: 338-344.

Neto JJ, Fracasso JF, Neves MCLC, Santos LE, Banuth VL 1996. Tratamento de úlcera varicosa e lesões de pele com Calendula officinalis L. e/ou com Stryphnodendron barbatiman (Veloso) Martius. Rev Cienc Farm 17: 181-186.

Nunes GP, Silva MF, Resende UM, Siqueira JM 2003. Plantas medicinais comercializadas por raizeiros no Centro de Campo Grande, Mato Grosso do Sul. Rev Bras Farmacogn 13: 83-92.

Panizza S, Rocha AB, Gecchi R, Silva RAPS 1988. Stryphnodendron barbatiman (Veloso) Martius: teor em tanino na casca e sua propriedade cicatrizante. Rev Cienc Farm. 10: 101-106.

Salminen J-P, Ossipov V, Haukioja E, Pihlaja K 2001. Seasonal variation in the content of hydrolysable tannins in leaves of Betula pubescens. Phytochemistry 57: 1522.

Santos SC, Costa WF, Ribeiro JP, Guimarães DO, Ferri PH, Ferreira HD, Seraphin JC 2002. Tannin composition of barbatimão species. Fitoterapia 73: 292-299.

Ward JH 1963. Hierarchical grouping to optimize na objective function. J Am Statist Assoc 58: 238-244. 